Frenchman or a Russian or a Scandinavian, or Planck, Boltzmann or Einstein, one can surely notice that each one means his own Lorentz. If a Netherlander has to mention the name Lorentz, he does it with pride, but softly, as if he fears that 'Perhaps Mr. Lorentz will be able to hear that he is being spoken about'."

J. HamiltoN

\section{GENERAL PLANT CELL PHYSIOLOGY}

Plant Physiology

A Treatise. Edited by F. C. Steward. Vol. 1A : Cellular Organization and Respiration. Pp. xxvii + 331. (New York : Academic Press, Inc. ; London : Academic Press, Inc. (London), Ltd., 1960.) 13 dollars.

HIS is the first volume in order of numbering
of the treatise on plant physiology in process of production under the general editorship of Prof. F. C. Steward, although it is actually the second to appear, the volume numbered 2 having already been noticed in these pages. Volume $1 A$ contains three articles, the first on the plant cell and its inclusions, the other's on some aspects of general plant cell physiology. It is desirable, indeod necessary, that a treatise on plant physiology should begin with an account of the cell, the system in which physiological actions take place, and R. Brown gives an account of this which is generally adequate and up to date. The conclusions drawn during recent years regarding cellular membranes, largely as a result of electron microscopy, are properly stressed, but as in all probability comparatively few readers will have had actual first-hand experience of the electron microscope, a brief description of how results are obtained by its use, and the reasons for the accepted interpretation of the structures so observed, might not have been out of place. These conclusions, it may be noted, in so far as they refer to the plasmatic membranes, fall well into line with those suggested by the conception of free space due to Briggs and Robertson.

The second article, by $\mathbf{B}$. Vennesland, is entitled "Proteins, Enzymes, and the Mechanism of Enzyme Action". There is reason to believe that protoplasmic proteins, at least in many cells, are largely held in enzymes, and this account deals mainly with enzyme structure, which includes the structure of protein molecules, and the mechanism of enzyme actions. No classification of enzymes has ever received universal acceptance, and the author does not attempt a new one. However, in dealing with enzyme reaction mechanisms three different kinds of enzymes are considered separately. These are : (1) oxidation-reduction enzymes containing firmly bound prosthetic groups; (2) enzymes containing thiamine or pyridoxine derivatives; (3) pyridine nucleotide-linked dehydrogenases, Other aspects of enzyme reactions considered are their kinetics, inhibitors, group transfers and the problem of the active site. The article provides a good and succinct account of the present position of our knowledge of enzyme structure and action.

The final article deals mainly with what is generally called the mechanism of respiration and gives satisfactory accounts of the various ways by which it is now supposed the respiratory substrates are broken down, though perhaps more attention might have been given to the action of lactic dehydrogenase leading to the formation of lactic acid. I cannot agree with the statement that the production of lactic acid from pyruvic acid is "relatively rare in higher plants, though traces of lactic acid are found in potato fermentation... and in wheat and rice". Actually the production of lactic acid has been observed in other plants, while in potatoes Barker found that at the beginning of a period of anaerobiosis the production of alcohol and carbon dioxide might be negligible in comparison with the production of lactic acid. In tomato stems a production of lactic acid recorded as amounting to 13.7 per cent of the carbon dioxide produced can scarcely be described as a trace. Again, I do not think that the acceptance of the universality of the EMP pathway was as surprising and uncritical as the authors suggest. And, was such a universality as dogmatically asserted as they say ? Surely it was no more than a tacit acceptance, a view which was readily modified when definite evidence of an alternative pathway was forthcoming.

The production of the volumes of this treatise is of the high quality we have come to associate with the publications of the Academic Press.

WALTER StILES

\section{BONDS, BANDS AND SEMICONDUCTORS}

\section{Progress in Semiconductors}

Vol. 5. Edited by Dr. Alan F. Gibson, Prof. R. E. Burgess and Dr. F. A. Kröger. Pp. vii +316. (London: Heywood and Co., Ltd., 1960.) 63s. net.

IS the band theory of semiconductors the modern I phlogiston theory? Lavoisier's discovery of oxygen brought about the downfall of the latter; by some eyes the discovery of vitreous and liquid semiconductors is seen as the herald of the fall of band theory. Others, less extreme, see a better historical analogy to the current band-bond battle in the wave-particle war and consequently expect an amalgamation of the two theories. Band theory has reached a high degree of sophistication, as is evidenced by most articles in the latest addition to this invaluable series of progress reports. The chemical bond approach discussed by E. Mooser and W. B. Pearson is by comparison in its infancy. The authors discuss rules derived from it for predicting semiconductivity (their own rule appears in a modified form which allows for cation-cation bonds), and then attempt to classify semiconduotors on the basis of their structures. In the concluding sections some intriguing ompirical graphs relating semiconductor and structural parameters are reproduced. Some discussion of alloy semiconductors, especially as regards superlattice formation, might have been included.

Optical properties, as the editors admit, predominate in this issue. T. P. MeLean reviews recent work on the absorption edge spectrum of semiconductors, in particular of germanium and silicon. B. Lax and S. Zwerdling have obviously striven to minimize the mathematics in their survey of magnetooptical phenomena. In the well-balanced meal they produce there is both meat for the specialist and gravy for the beginner. T. S. Moss, in a short 